\title{
PELATIHAN METODOLOGI PENELITIAN TINDAKAN KELAS DAN TEKNIK PENULISAN ILMIAH PADA GURU SMP NEGERI 3 TONDANO KABUPATEN MINAHASA
}

\author{
Mercheane V. M. Pontoh \\ Fakultas Ekonomi, Universitas Negeri Manado
}

\begin{abstract}
Abstrak
Guru adalah ujung tombak pelaksana kegiatan pendidikan di sekolah. Keberhasilan dalam kegiatan pendidikan sangat ditentukan oleh keberhasilan guru dalam melaksanakan kegiatan pembelajaran di kelas. Kebutuhan untuk meningkatkan kualitas pembelajaran antara lain dapat dilakukan dengan melaksanakan kegiatan penelitian tindakan kelas secara berkelanjutan oleh para guru di sekolah. Oleh sebab itu kepada para guru di SMP Negeri 3 Tondano dianggap penting untuk mendapatkan pelatihan tentang metodologi PTK dan teknik penulisan ilmiah sehingga setelah selesai melaksanakan PTK langsung dapat diikuti dengan pelaporannya. Kegiatan pelatihan tersebut telah dilaksanakan pada bulan April 2016. Hasil kegiatan pelatihan tersebut yaitu telah terjadi peningkatan pengetahuan tentang metodologi penelitian tindakan kelas dan keterampilan dalam penulisan laporan hasil penelitian. Peningkatan pengetahuan tersebut ikut meningkatkan kesadaran dan motivasi untuk melakukan perbaikan dalam proses pembelajaran dan mengevaluasi hasilnya melalui kegiatan reflektif yang menjadi salah satu komponen dalam PTK. Oleh sebab itu ke depan diharapkan kegiatan pelatihan sejenis dapat terus dilaksanakan.

Kata Kunci: Pelatihan Metodologi PTK, Teknik Penulisan Ilmiah, Guru SMP Negeri 3 Tondano.
\end{abstract}

\section{PENDAHULUAN}

\section{Analisis Situasi}

$$
\text { Guru adalah ujung tombak }
$$

pelaksana kegiatan pendidikan di sekolah. Keberhasilan dalam kegiatan pendidikan sangat ditentukan oleh keberhasilan guru dalam melaksanakan kegiatan pembelajaran di kelas. Masnur Muslich menyatakan bahwa "dipundak gurulah keberhasilan pembelajaran dipertaruhkan dan hanya guru yang berdedikasilah yang mau terbuka terhadap perubahan dan pembaharuan".

Di SMP Negeri 3 Tondano, pada saat ini terdapat keluhan-keluhan para guru yaitu tentang pelaksanaan penelitian tindakan kelas dimana pada satu sisi guru sangat membutuhkan pelatihan tentang metodologi penelitian tindakan kelas guna kebutuhan peningkatan kinerja tetapi pada sisi lainnya sampai saat ini belum semua guru dapat diikut-sertakan, padahal mereka memiliki kebutuhan yang sama.

Salah satu upaya untuk memperbaiki kualitas kinerja guru adalah dengan melakukan penelitian tindakan kelas sebagai suatu bentuk penelitian yang bersifat reflektif dengan mengkaji tindakan-tindakan yang dilakukan guru di kelas agar supaya dapat diperbaiki dan ditingkatkan mutu proses pembelajaran secara berkelanjutan.

$$
\text { Semakin sering dan semakin }
$$
intensifnya guru melakukan penelitian tindakan kelas, maka semakin efektif juga realisasi untuk peningkatan mutu pembelajaran, sekaligus juga akan 
berdampak pada peningkatan mutu pendidikan secara keseluruhan.

Dalam pengembangan profesionalisme guru terdapat lima jenis kegiatan yang perlu dilakukan guru yaitu:

1. Menghasilkan karya tulis ilmiah di bidang pendidikan;

2. Menemukan teknologi tepat guna bidang pendidikan;

3. Menciptakan alat peraga;

4. Menghasilkan karya seni; dan

5. Mengikuti kegiatan pengembangan penyempurnaan kurikulum.

Terdapat permasalahan yang sesungguhnya menjadi keprihatinan dalam usaha untuk meningkatkan mutu pendidikan yaitu rendahnya pengetahuan guru tentang metodologi penelitian tindakan kelas. Padahal untuk meningkatkan mutu pendidikan dan profesionalisme guru, maka guru harus meningkatkan pengetahuannya antara lain dengan melakukan kajian secara berkelanjutan terhadap pelaksanaan tugasnya di kelas melalui kegiatan penelitian tindakan kelas.

Permasalahan yang dihadapi para guru di sekolah dalam melakukan penelitian tindakan kelas adalah:

1. Kurangnya pengetahuan tentang metodologi penelitian tindakan kelas;

2. Rendahnya budaya mutu dalam hal melakukan perbaikan secara sistematis dan berkelanjutan melalui kegiatan penelitian. Kegiatan penelitian belum dijadikan sebagai kegiatan utama yang dilakukan secara terstruktur dalam pelaksanaan tugas sebagai guru; dan

3. Hampir sebagian besar guru nanti berupaya "mencari laporan penelitian" ketika ingin mengajukan kenaikan pangkat. Kondisi seperti inilah yang menyebabkan banyak hasil penelitian "asli tetapi palsu". Biaya untuk melengkapi persyaratan kenaikan pangkat menjadi sangat tinggi karena guru belum mampu melakukan penelitian secara mandiri, tetapi mau mendapatkan kenaikan pangkat yang berarti mendapatkan kenaikan gaji termasuk jabatan tertentu.

Dengan demikian dibutuhkan usaha yang sistematis guna meningkatkan pengetahuan guru tentang metodologi penelitian tindakan kelas sehingga guru benar-benar mampu untuk melakukannya dan profesionalisme guru benar-benar terwujud.

Salah satu usaha untuk meningkatkan pengetahuan guru tentang metodologi penelitian tindakan kelas dapat dilakukan melalui pelatihan penelitian tindakan kelas. Inilah salah satu solusi yang dapat ditawarkan guna mengatasi kurangnya pengetahuan guru dalam melakukan penelitian tindakan kelas.

\section{Target dan Luaran}

Target yang ingin dicapai dalam kegiatan pelatihan ini adalah terjadinya peningkatan pengetahuan guru tentang meto- 
dologi penelitian tindakan kelas sehingga dapat menghasilkan dan bermanfaat untuk:

1. Memperbaiki dan meningkatkan mutu proses pembelajaran di kelas;

2. Meningkatkan profesionalisme guru;

3. Mempermudah guru melengkapi persyaratan kenaikan pangkat dan usulan untuk promosi lainnya;

4. Memotivasi guru untuk terus melakukan kajian secara berkelanjutan;

5. Mengoptimalkan kemampuan guru dan mempertebal rasa percaya diri guru sebagai sosok yang patut dibanggakan karena mampu menghasilkan temuantemuan secara ilmiah di bidang pendidikan;

6. Meminimalisir dampak negatif supervisi dan audit kinerja karena guru mampu melakukan self-evaluation; dan

7. Mendukung program penjaminan mutu secara berkelanjutan yang sedang digagas oleh pemerintah.

\section{METODE PELAKSANAAN}

Salah satu usaha untuk meningkatkan pengetahuan guru tentang metodologi penelitian tindakan kelas dapat dilakukan melalui pelatihan penelitian tindakan kelas. Inilah salah satu solusi yang dapat ditawarkan guna mengatasi kurangnya pengetahuan guru dalam melakukan penelitian tindakan kelas.

Sehubungan dengan permasalahan yang telah diuraikan maka solusi yang ditawarkan yaitu PELATIHAN METODOLOGI PENELITIAN TINDAKAN
KELAS DAN DILANJUTKAN DENGAN TEKNIK PENULISAN ILMIAH bagi seluruh guru di SMP Negeri 3 Tondano.

Kegiatan pelatihan ini dilaksanakan pada guru di SMP Negeri 3 Tondano, dengan tahapan pelaksanaan kegiatan sebagai berikut:

1. Tahap pertama, persiapan pelaksanaan kegiatan dalam bentuk koordinasi dengan Dinas Pendidikan, UPT dan Kepala Sekolah; dan

2. Tahap kedua, pelaksanaan pelatihan dengan materi sebagai berikut :

- Hakekat PTK

- $\quad$ Sifat, Karakteristik dan Prinsip PTK

- Model-Model PTK

- Prosedur Pelaksanaan PTK

- Penyusunan Proposal PTK

- Pelaporan Hasil PTK

- Teknik Penulisan Ilmiah

3. Tahap ketiga, evaluasi kegiatan dan pelaporan hasil pelaksanaan pelatihan.

Dalam kegiatan pelatihan "Penelitian Tindakan Kelas" pada guru di SMP Negeri 3 Tondano, maka luaran atau hasil kegiatan yang diperoleh, yaitu: peningkatan pengetahuan para peserta tentang metodologi penelitian tindakan kelas, setiap guru dapat menyusun proposal penelitian sesuai dengan permasalahan nyata yang dihadapi di kelasnya, dan pelaksanaan dan hasil kegiatan pelatihan yang meliputi hal-hal seperti yang terlihat dalam bagan Gambar 1. 


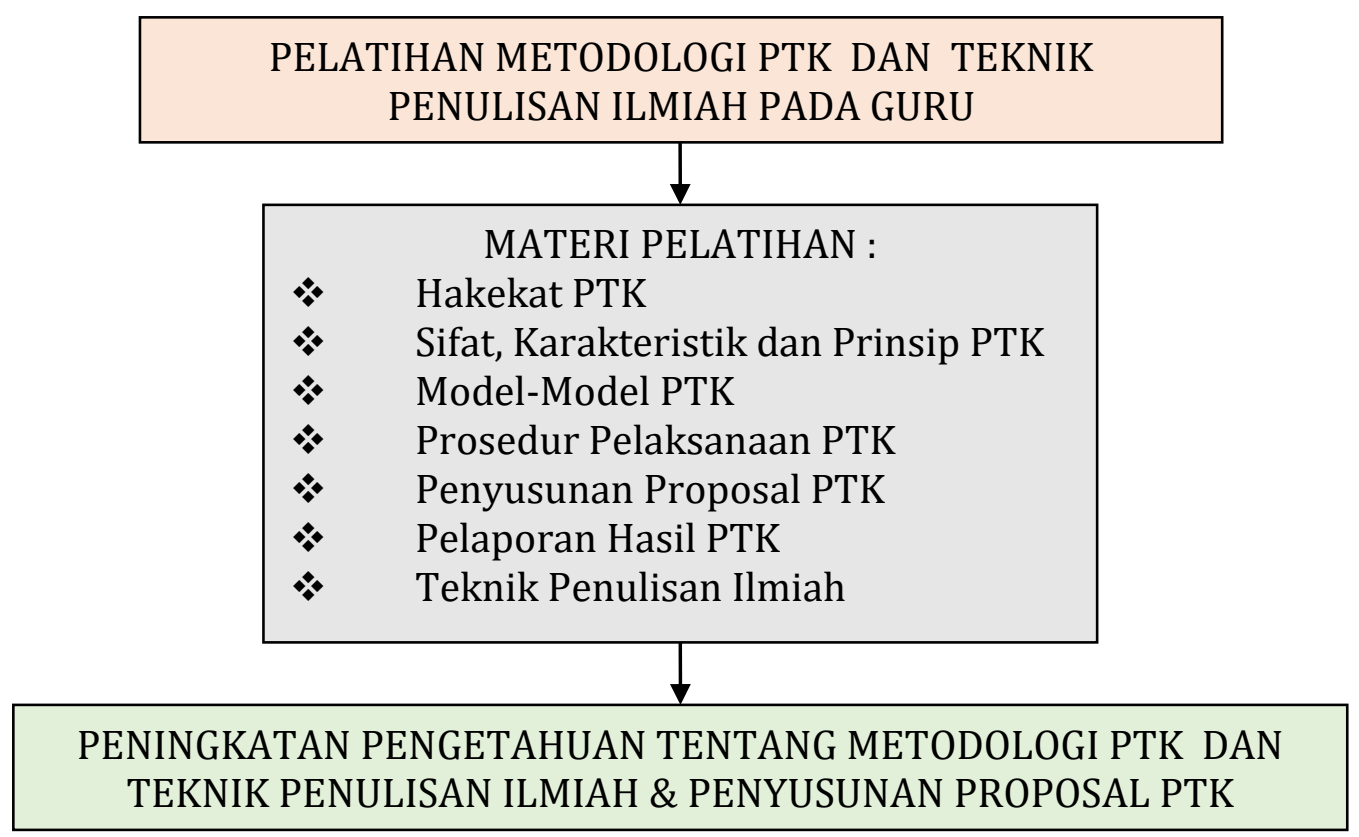

Gambar 1. Bagan Pelaksanaan Pengabdian Kepada Masyarakat

\section{HASIL DAN PEMBAHASAN}

Sesuai dengan rencana yang telah disusun dalam kerangka pemecahan masalah yang dihadapi oleh mitra di lapangan maka kegiatan pengabdian kepada masyarakat telah dilaksanakan khususnya kegiatan pelatihan Metodologi Penelitian Tindakan Kelas dan Teknik Penulisan Karya Ilmiah telah dilaksanakan pada bulan April 2016.

Kegiatan awal yang telah dilakukan yaitu koordinasi pelaksanaan kegiatan, menyiapkan materi pelatihan, menyiapkan baliho untuk pelaksanaan kegiatan pelatihan, melaporkan pelaksanaan kegiatan kepada Kepala Sekolah Menengah Pertama Negeri 3 Tondano di Tataaran 1 Kecamatan Tondano Selatan Kabupaten Minahasa Provinsi Sulawesi Utara, Ibu. Hanna Kamagi, S.Pd, M.Pd.

Pelaksanaan pelatihan telah diawali dengan sambutan pihak sekolah yang telah dibawakan oleh Kepala Sekolah Menengah
Pertama Negeri 3 Tondano Ibu Hanna Kamagi, S.Pd., M.Pd dan dilanjutkan dengan doa oleh Ibu Achnes S. Moningka, S.Th.

Hasil pelaksanaan kegiatan pelatihan Metodologi Penelitian Tindakan Kelas dan Teknik Penulisan Karya Ilmiah pada guru Sekolah Menengah Atas Negeri 3 Tondano tampak pada hasil evaluasi kegiatan yang dilakukan setelah kegiatan pelatihan berakhir.

Pimpinan sekolah dalam hal ini kepala sekolah dan wakil kepala sekolah begitu antusias untuk ikut serta dalam pelatihan. Hal ini tampak pada keikutsertaan kepala sekolah selama kegiatan pelatihan berlangsung. Dengan demikian para guru ikut serta mencermati materi pelatihan yang dipaparkan oleh tim pelaksana kegiatan pengabdian kepada masyarakat.

Berdasarkan hasil observasi terhadap pelaksanaan kegiatan pelatihan 
yang telah dilakukan dapat dinyatakan bahwa kegiatan ini dapat dilaksanakan sesuai rencana yang telah ditetapkan. Meskipun demikian masih terdapat beberapa kendala yaitu sasaran kegiatan untuk penyusunan proposal PTK belum sepenuhnya dapat direalisasikan. Namun dari segi penguasaan materi tampak hasilnya yaitu terjadi peningkatan pengetahuan terhadap materi pelatihan yang disajikan. Penguasaan materi ini terkait juga dengan pengetahuan awal yang telah dimiliki oleh sebagian besar guru yang ada.

Hasil lainnya yaitu adanya usulan dari beberapa guru agar kegiatan yang sama dapat terus dilakukan di masa mendatang bukan hanya di sekolah tempat latihan tetapi juga di sekolah lainnya mengingat rekan guru lainnya sangat membutuhkan peningkatan pengetahuan seperti halnya di sekolah yang telah dilayani.

Dengan demikian tampak jelas bahwa pada hakekatnya penelitian tindakan kelas dapat menciptakan kesadaran dan motivasi kepada paraguru untuk dapat memperbaiki dan meningkatkan kualitas proses pembelajaran beserta hasil-hasil capaiannya baik untuk kebutuhan di kelasnya maupun untuk menjadi acuan bahkan model di kelas lainnya yang memiliki kesamaan karakteristik.

Selanjutnya melalui penguasaan metodologi penelitian tindakan kelas guru menjadi semakin professional dalam pelaksanaan tugasnya, karena guru bukan hanya sebagai pendidik tetapi sekaligus juga sebagai peneliti.

\section{KESIMPULAN DAN SARAN}

Peningkatan kualitas pendidikan dapat dilakukan dengan meningkatkan kualitas kinerja guru. Salah satu upaya untuk memperbaiki kualitas kinerja guru adalah dengan melakukan penelitian tindakan kelas sebagai suatu bentuk penelitian yang bersifat reflektif dengan mengkaji tindakan-tindakan yang dilakukan guru di kelas agar supaya dapat diperbaiki dan ditingkatkan mutu proses pembelajaran secara berkelanjutan.

Semakin sering dan semakin intensifnya guru melakukan penelitian tindakan kelas, maka semakin efektif juga realisasi untuk peningkatan mutu pembelajaran, sekaligus juga akan berdampak pada peningkatan mutu pendidikan secara keseluruhan.

Melalui kegiatan pengabdian pada masyarakat, maka perguruan tinggi dapat memberikan kontribusi yang signifikan dalam peningkatan dan perbaikan kinerja guru melalui pelatihan penelitian tindakan kelas. Antusiasme para guru terhadap pelaksanaan pelatihan Metodologi Penelitian Tindakan Kelas dan Teknik Penulisan Karya Ilmiah menunjukkan adanya kebutuhan dan motivasi untuk berprestasi dan meningkatkan kinerja mereka.

Hasil analisis yang telah disimpulkan menunjukkan adanya kebutuhan para guru untuk terus meningkatkan pengetahu- 
an tentang Metodologi Penelitian Tindakan Kelas dan Teknik Penulisan Karya Ilmiah. Dengan adanya kebutuhan terhadap peningkatan pengetahuan seperti itu maka selayaknya perguruan tinggi dapat merespons secara proaktif guna menindaklanjuti hal tersebut. Oleh sebab itu maka disarankan agar pihak perguruan tinggi dapat memprogramkan kegiatan pengabdian kepada masyarakat ke depannya dengan terus memperhatikan kebutuhan peningkatan pengetahuan para guru secara berkelanjutan. Peningkatan kualitas di antaranya adalah peningkatan pengetahuan secara berkelanjutan.

\section{KEPUSTAKAAN}

Cresswell, John W. Educational Research : Planning, Conducting, and Evaluating Quantitative and Qualitative Research, New Jersey : Pearson Education, Inc. 2008.

Ekawarna, Penelitian Tindakan Kelas, Jakarta : Gaung Persada, 2010.

Haris Herdiansyah, Metodologi Penelitian Kualitatif Untuk Ilmu-Ilmu Sosial, Jakarta : Salemba Humanika, 2010.

Masnur Muslich, KTSP : Pembelajaran Berbasis Kompetensi dan Kontekstual Panduan Bagi Guru, Kepala Sekolah dan Pengawas Sekolah, Jakarta : Bumi Aksara. 2008.

Sugiyono, Memahami Penelitian Kualitatif, Bandung : Alfabeta, 2008. 